\title{
SOCIAL INVESTMENT IN SPAIN: HOW DO SOLIDARITY MUTUAL FUNDS DECIDE THE ALLOCATION OF SOLIDARITY FUNDING BETWEEN SOCIAL ECONOMY ORGANIZATIONS?
}

\author{
by \\ Francisco J. LÓPEZ-ARCEIZ, Ana J. BELLOSTAS* and \\ Pilar RIVERA-TORRES \\ Universidad de Zaragoza, Spain
}

\begin{abstract}
Solidarity mutual funds (SMFs) are a financial product oriented toward funding social economy organizations (SEOs). The main characteristic of these mutual funds, known in other countries as social investment, is that part of their management fees is allocated to support SEOs. In Spain, the criteria used in the allocation process of these funds have not been studied. The aim of this paper is to analyze the decision model of SMFs. To this end, we developed a logit regression model. The obtained results show that the decision model of SMFs promotes the development of commercial activity and favors a specific ideology and values and an exclusive relationship with the main funders.
\end{abstract}

Keywords: solidarity mutual funds, decision model, social investment, social economy organizations

\section{$1 \quad$ Introduction}

Nowadays, in the European Union, there is an ongoing debate between two approaches of economic thought: neoliberalism and neo-Keynesianism (Patomaki 2009; Schmidt 2016). Neoliberalism tends to regard the market as a tool for the redistribution of wealth and welfare, whereas neo-Keynesianism argues for the intervention of social agents and governments as a way to combat market failures. Chaves et al. (1999) regarded neo-Keynesianism as the basis of the European social economy due the economic functions of the social economy. In their opinion, the social economy is a tool to promote, among others, the distribution of wealth, the autonomy of regions, employment, and sustainable development. As a consequence, social economy organizations (SEOs) are promoted by the European Union as a response toward correcting social and regional imbalances. SEOs are chosen as strategic instruments of social, economic, and fiscal policies; they are flexible organizations with the capacity to develop multiobjective management.

E-mail: bellosta@unizar.es

Annals of Public and Cooperative Economics @ 2017 CIRIEC. Published by John Wiley \& Sons Ltd, 9600 Garsington Road, Oxford OX4 2DQ, UK and 350 Main Street, Malden, MA 02148, USA 
Despite such promotion, Spanish SEOs have faced a drastic reduction of 11 per cent on average in public subsidies in the last few years (PwC Foundation 2013). At the same time, the Spanish government has decreased by 24.70 per cent public expenses for social services and the promotion of employment, which SEOs rely on. Given this situation, these entities must search for alternative funds in the financial markets. Financial markets have evolved from a vision based exclusively on financial criteria to one into which non-financial criteria have been introduced (Renneboog et al. 2008a). This evolution led to the development of socially responsible investment. Under this denomination, financial organizations have designed new socially responsible financial products although entities that are into socially responsible need to develop new strategies if they want to survive. The solidarity component is one step forward in the strategy of these entities.

Solidarity funding can be a key tool in the social economy in the process of economic recovery (Prouteau and Tchernonog 2015). However, the criteria used by solidarity funders, such as solidarity mutual funds (SMFs), in deciding on the allocation of this sort of funding are not known. The aim of the present study is to analyze the decision model of SMFs and to determine the criteria applied by these funds in designing the allocation of funding. To achieve this aim, we used the population of Spanish SMFs and a sample consisting of 350 SEOs that they support. The obtained results show that the decision model of SMFs promotes the development of commercial activity and favors a specific ideology and values and an exclusive relationship with the main funder.

The paper is structured as follows. The second section provides a review of the research in this field and the various hypotheses studied in the present work. In the third section, the data, variables, and descriptive statistics are presented to support the proposed hypotheses. The fourth section shows the results and provides the conclusions.

\section{Theoretical framework}

\subsection{Social economy organizations: Concept and characteristics}

In Europe, SEOs are regarded as an alternative way to generate economic and social welfare and as a new tool of European social policies (EU Strategy 2020). In spite of this promotion by the European Union, however, relatively little is known about the scale and characteristics of these entities (EESC 2015). This lack of knowledge has its origin in the diversity of experiences at the regional level, as well as of national economic structures, welfare systems, cultural traditions, and legal frameworks (Kerlin 2006; Quintão 2007; Defourny and Nyssens 2008; Hulgård 2010; Fayolle and Matlay 2010). Following the European trend, SEOs in Spain can be found among some workerowned entities, such as cooperatives, and some organizations, including foundations and associations (EESC 2015; AECA 2015).

SEOs have a hybrid nature and are not aligned with the traditional idealized categories, namely, the public, private, and nonprofit sectors (Billis 2010; Wilson and Post 2013; Doherty et al. 2014). This hybrid character, in which economic and social 


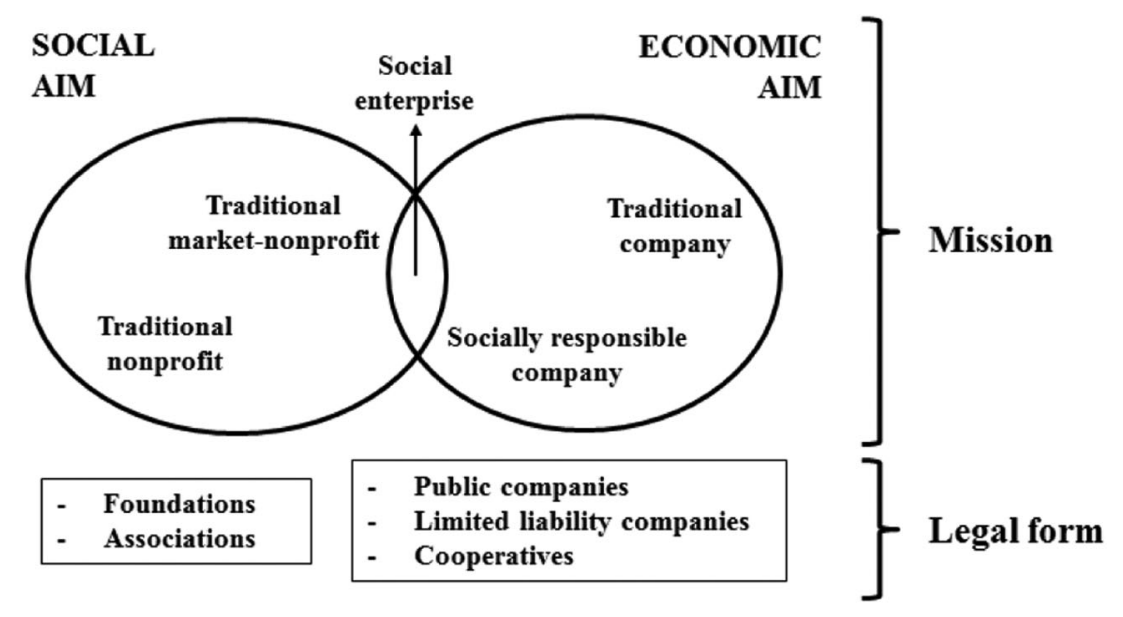

Figure 1 - Classification criteria related to social economy organizations.

activities coincide, influences the mission and legal form of the organization (Emerson 2006). However, there is a divergence in the relationship between these activities and the possible legal forms that these entities can adopt. Regarding the mission, some authors, such as Porter and Kramer (2006, 2012) and, more recently, Doherty et al. (2014), establish the possibility that these entities pursue social and economic aims at the same time (dual mission). Consequently, under this approach, there is only one behavioral model. In contrast, Borzaga and Galera (2014) and Pirson (2012) argue that a dual aim is not possible in the practice. In this case, hybrid organizations will develop different behaviors depending on their priority aim. Taking into account this last approach, LópezArceiz et al. (2016) distinguished three hybrid behavioral models that consider the role of the social and economic mission: (a) socially responsible companies, (b) social enterprise, and (c) market-oriented nonprofit.

If the legal nature is used as an alternative classification criterion, we can distinguish between public sector, for-profit private sector, and nonprofit private sector. In the nonprofit private sector, we can find foundations and associations, whereas in the forprofit sector, we have public companies, limited liability companies, and cooperatives, among others. This categorization is based on the legal nature and not on the mission of the entity. In other words, an entity with the same legal form can develop a dual mission but can also develop a priority aim, be it social or economic. Thus, the legal nature is not conditioned by the mission of the entity.

Figure 1 shows both criteria. A foundation or association will develop a priority social aim although it can manage some resources for its economic activity. In this case, the economic activity is a financial tool of the social aim. In contrast, a for-profit private entity (such as a public company, limited liability company, or cooperative) will pursue an imperative economic aim and could develop a social activity; such entity could even have a priority social aim, such as sheltered workshops or work integration social enterprises (WISEs). Therefore, the mission of the entity and the development of its social and economic activities will not depend on its legal nature. 
The most controversial element in Figure 1 is the identification of a social enterprise. According to a recent map of social enterprises in Europe (Wilkinson et al. 2015), it is possible to consider as social enterprises some associations or foundations and other for-profit private entities (public companies, limited liability companies, or cooperatives). In all these entities, the social aim is always a priority, and the development of continuous and stable economic activity is necessary (López-Arceiz et al. 2016).

The origin of this controversy is the overlap between the mission and the legal form criteria. Some authors base their definitions of social enterprise on the legal form (AECA 2015). Under this approach, a social enterprise is defined as a legal entity originated in the Third Sector that develops social and economic activities. However, other authors (Bellostas et al. 2016; López-Arceiz et al. 2016) base their definition of social enterprise on the relationship between economic and social activities. Following this approach, social enterprises, market-oriented nonprofits, and traditional nonprofits are considered as SEOs because they have an imperative social aim. However, the role of the economic activity differs. In a social enterprise, the economic activity is mandatory, whereas in a market-oriented nonprofit, such activity is incidental. In contrast, a traditional nonprofit does not develop any economic activity. This approach, which is based on the mission of the entity, represents the hybrid nature of an SEO by reflecting its behavioral model.

The hybrid nature of an SEO can be defined based on three dimensions: social, entrepreneurial, and inclusive (Defourny and Nyssens 2008). The social dimension of these entities is defined by the aim and/or products delivered (Borzaga and Galera 2014). This dimension is more developed in traditional nonprofits because such entities focus on a social aim. The economic or entrepreneurial dimension consists of carrying out stable and continuous economic activities. This dimension is promoted specially in social enterprises. Finally, the inclusive dimension refers to the participation of stakeholders in the organization (Galera 2015). This aspect tends to be potentiated in all the entities given that they are created to answer the needs of a broad spectrum of stakeholders. These three dimensions thus provide the basic characterization of an SEO.

\subsection{Funding social economy organizations in Spain: Solidarity mutual funds}

The hybrid character of SEOs and the difficulty of differentiating between their legal nature and mission can condition the type of funding available for these entities. In this sense, Doherty et al. (2014) identify an advantage of this lack of definition, that is, the possibility of obtaining funds from both market and nonmarket sectors. Traditionally, markets have proportionated funding through commercial banks and the stock exchange. This sort of funding was designed to promote the economic viability of companies and businesses (Kingston and Bolton 2004). Additionally, from the nonmarket subsector, Public Administration and private savers have supported foundations and associations through grants (Jaliu and Ravar 2013) and charitable funds (Kingston and Bolton 2004). The key aim of these funders was to promote projects with social impact.

The change in European economic thought, oriented toward promoting sustainable socioeconomic activity (Cheruvalath 2016), has led financial markets and organizations to offer products that combine the characteristics of traditional funding and the typical elements of funding from the nonmarket subsector (Liket and Maas 2016). Nowadays, commercial banks and financial markets compete to get socially responsible 
Table 1 - Developed strategies in mutual funds

\begin{tabular}{|c|c|c|c|c|c|c|}
\hline & Traditional & Responsible & Sustainable & Thematic & Solidarity & Philanthropic \\
\hline Aim & $\begin{array}{l}\text { Maximization } \\
\text { of financial } \\
\text { return }\end{array}$ & $\begin{array}{l}\text { Restricted by } \\
\text { selective } \\
\text { criteria }\end{array}$ & $\begin{array}{l}\text { Use of value } \\
\text { criteria }\end{array}$ & $\begin{array}{l}\text { Cluster by } \\
\text { activity area }\end{array}$ & $\begin{array}{l}\text { Funding of } \\
\text { social } \\
\text { projects }\end{array}$ & $\begin{array}{l}\text { Creation of a } \\
\text { social } \\
\text { project }\end{array}$ \\
\hline Example & $\begin{array}{l}\text { Fixed income } \\
\text { mutual } \\
\text { funds }\end{array}$ & $\begin{array}{l}\text { Selective } \\
\text { funds drugs } \\
\text { industry }\end{array}$ & $\begin{array}{l}\text { ASG mutual } \\
\text { funds }\end{array}$ & $\begin{array}{l}\text { Ecological } \\
\text { mutual } \\
\text { funds }\end{array}$ & $\begin{array}{l}\text { Solidarity } \\
\text { mutual } \\
\text { funds }\end{array}$ & $\begin{array}{l}\text { Founding } \\
\text { Disbursed } \\
\text { funds }\end{array}$ \\
\hline
\end{tabular}

Sources: Own based on Bridges Venture 2012.

investors through financial innovations that serve as alternatives to traditional financial products. Among these financial innovations, solidarity funding or social investment is highlighted. This type of funding can be described as consisting of a range of activities designed to motivate and mobilize business leaders to become a force toward positive change in business practices for the benefit of stakeholders (Dillenburg et al. 2003). This investment mode is developed under different types of financial products (including mutual funds, pension plans, and philanthropic initiatives, among others). ${ }^{1}$

In Spain, solidarity investment is considered as part of the socially responsible financial market (Lozano et al. 2006). In general, socially responsible investing applies financial and nonfinancial criteria in the selection of socially responsible companies to include in their portfolio (Renneboog et al. 2008a, 2008b; Crifo and Mottis 2016). However, solidarity investment pursues a complementary aim, the funding of a social project or initiative. When the solidarity investment takes the form of an SMF, the fund managers donate part of their management fees to an identified SEO (INVERCO 1999, 2014). According to the Spanish legal framework (Law 35/2003 - Collective Investment Institutions Act), mutual funds require the convergence of two agents: Holder banks (commercial banks, saving banks and credit unions) and manager societies. The holder bank has to guard the financial assets which compose the portfolio of the mutual fund while the manager society decides the investment strategy. ${ }^{2}$ In the case of SMFs, the manager society has to decide the entities which are beneficiaries of the management fees, this behavior being the main characteristic of these mutual funds.

As a consequence, SMFs are a step forward in socially responsible investment (Bridges Ventures 2012). Table 1 shows the different strategies that can be developed by mutual funds in the context of socially responsible investment.

As we can observe in Table 1, SMFs are a financial product that focuses not only on the portfolio composition according to the traditional criteria of maximum return for

1 Different solidary financial products can be found worldwide. Jégourel and Maveyraud (2009) cited a type of solidarity mutual fund in France. In other countries, this product is known as impact investment (Stagars 2014; Wilson 2014).

2 Valor et al. (2007) detected that commercial banks are leaders of Socially Responsible Investment market in Spain. About ten years later, this situation is still true. Santander and BBVA are the main entities in the Spanish market. However, when we study solidarity mutual funds (also called sharing funds), we detect a strong participation of saving banks and credit unions. In fact, approximately 50 per cent of the solidarity mutual funds which survive the economic crisis has its origin in the latter entities (Bellostas and López-Arceiz 2014). 
a determined level of risk. Rather, these mutual funds include a new element: funding social projects. The socially responsible market in Spain has undergone a gradual evolution. In 2003, a 20 per cent of SMFs added the solidarity component to their strategy (Lozano et al. 2006). By 2014, mutual funds with the solidarity component had reached about 50 per cent (Social Investment Forum 2014). Solidarity investment, and SMFs, has a more ambitious pursuit of funding an SEO. Thus, the decision-making process is more complex because these entities have to decide on the portfolio composition and the allocation of management fees among a pleiad of SEOs. Moreover, the managers of these mutual funds have to consider that an SEO can be valued based on different dimensions (economic, social, and inclusive).

If the decision model of the SMF is similar to that of a traditional commercial bank, it is reasonable to consider the level of economic activity developed by the SEO as the most important element. To test this statement, we propose the following working hypothesis:

$\mathbf{H}_{1}$ : The economic activity of the social economy organization is a decision criterion when an ESFM determines the allocation of solidarity funding.

We do not expect $\mathrm{H}_{1}$ to be rejected because the level of economic activity of the social entity could be a decision criterion for an SMF. However, if an SMF considered only the economic activity of the SEO, this kind of financial product would be considered as a marketing tactic of the holder bank, with the social entity being a customer of the financial institution. In this case, the holder bank invests in marketing assets and expects these assets to contribute to profits in the short run and to provide potential for growth and sustained profits in the long run (Rust et al. 2004). In this approach, an SMF could be considered as a kind of premium or customer loyalty product for social entities that maintain positive cash flows in the holder bank.

Given the nature of an SEO, the social dimension is an important aspect of this kind of entity. This dimension is usually described as the number of attended users or the creation of employment (Mano 2014, 2015; López-Arceiz et al. 2016). Some studies in the framework of microfinance institutions have shown that both elements are measurements of the level of commitment to the social aim and that these elements are taken into account in the decision-making process (Evans 1999; Navajas et al. 2000; GutierrezNieto et al. 2009). In the case of an SMF, the social activity should be a criterion in its decision model. We therefore test our second hypothesis:

$\mathbf{H}_{2}$ : The social activity of the social economy organization is a decision criterion when an ESFM determines the allocation of solidarity funding.

An SEO pursues a social mission; thus, it is difficult for the funder not to take into account this characteristic. For this reason, we expect $\mathrm{H}_{2}$ to be supported. If an SEO is able to employ more human resources or attend to a higher number of users, its ability to attract solidarity funding will increase. However, if this was the unique criterion, the behavior of these entities would be based on the allocation criteria which would be closer to a public grant. In this case, the SMF would become a kind of public agency tasked with monitoring the allocation of funding. 
Finally, the inclusive dimension could also influence the decision of an SMF. This aspect has been studied in relation to the portfolio composition of ethical/socially responsible mutual funds (Entine 2003; Muñoz-Torres et al. 2004; Girard et al. 2007). Previous research has shown that ideological aspects related to the investee companies can determine the portfolio composition of an ethical/socially responsible mutual fund (Bellostas and López-Arceiz 2014). Consequently, the level of participation of the organization stakeholders could also affect the decision-making processes of the mutual fund. For this reason, we test the following hypothesis:

$\mathbf{H}_{3}$ : The participation of the stakeholders or inclusive dimension in the social economy organization is a decision criterion when an ESFM determines the allocation of solidarity funding.

In the context of SEOs, this dimension can be related to constraints in the distribution of profits, the organizational autonomy, and, especially, the degree of integration of the needs of stakeholders. If an SMF only financed an SEO that enables the fund to participate in the corporate bodies, the SEO could be considered as an affiliated company of the mutual fund. In this case, the allocation criterion would be something discretional based on the trust and interpersonal relationship between the managers of the SEO and of the mutual fund.

In short, the characteristics of an SEO could be an active component of the decision model of SMFs. In any case, we expect the manager of an SMF to consider these three dimensions when deciding on the allocation of solidarity funding. However, the promotion of one dimension to the detriment of the rest would introduce disequilibrium in the allocation criteria as it has been exposed.

\section{$3 \quad$ Methodology}

\subsection{Sample}

The studied sample consists of the population of SMFs in Spain. According to the National Stock Market Commission (Comisión Nacional del Mercado de Valores, CNMV), there are at present eight SMFs, which support the economic and social activities of 951 SEOs. These social organizations are heterogeneous in their activities: 72 per cent of which are related to health care, 25.43 per cent to cooperation and development, and the rest to social services $(1.14 \%)$, religious activity $(0.57 \%)$, education $(0.29 \%)$, trade unions $(0.29 \%)$, and cultural activities $(0.29 \%)$. There is diversity at the regional level. However, there is a notable concentration in three areas: Madrid, Catalonia, and Pays Basque.

We obtained information on the financial activities of the different solidarity mutual funds from the National Stock Market Commission. Information on the social entities was extracted from the annual accounts and activity reports of the SEOs, which were obtained from corporate registers and the different ministries and regional governments. ${ }^{3}$ All in all, data for a sample of 365 SEOs was collected.

3 This information was extracted from a public register known as Protectorado de Fundaciones and may have come from either the Ministry of Justice of the Central Government or the Department of Justice of the Regional Governments. 


\subsection{Main variables}

Taking into account the dimensions of an SEO, we propose the following variables:

- Economic activity. The measurement of the economic activity in an organization can be developed from two alternative models (Ortas and Moneva 2011): market valuation and accounting valuation. According to Van Beurden and Gössling (2008), accounting measurements offer an assessment of the efficiency of the company decision-making process, whereas measurements based on market value provide the perceptions of the participants in the financial markets.

In this study, given the variety of legal forms, accounting measurements are used, particularly return on assets (ROA) and return on equity (ROE). These indicators have been used in previous research within the framework of SEOs as indicators of economic efficiency (Ramayah et al. 2011; Sanchis-Palacio et al. 2013; Tan and Yoo 2015). However, although ROA and ROE incorporate the idea of efficiency, they could be biased by the denominators. Thus, two measurements of economic activity are added, net sales $(\ln ($ sales $))$ and net profit $(\ln ($ net profit)). These indicators have also been used in previous papers (Di Zhang and Swanson 2013; Rahim et al. 2015; Bellostas et al. 2016).

- Social activity. The concept of social activity originated in the field of economic research over 20 years ago; however, thus far, there is no generally accepted way to measure this variable (Bellostas et al. 2016). In general, SEOs measure social activity in relation to the human resources employed and involved in the organization (employees, volunteers, and end users). This approach was developed by academics and practitioners. In the academia, for example, Mano $(2014,2015)$ and López-Arceiz et al. (2016) argued that the levels of employment, volunteering, and users are proxies of the generation of social activity by an SEO. Among practitioners, some legal frameworks established this measurement criterion. Specifically, in Spain, resolutions on March 26, 2013 (BOE no. 85 on 9 April 2013, and BOE no. 86 on 10 April 2013), also followed this orientation.

In the present paper, these indicators are relativized by constructing three families of ratios: (a) the ratios of assets (ACT/T), gross income (IE/T), and public grants (SUBV/T) to employees; (b) the ratios of assets (ACT/V), gross income (IE/V), and public grants (SUBV/V) to volunteers; and (c) the ratios of assets (ACT/U), gross income (IE/U), and public grants (SUBV/U) to users. The level of assets considers the investment of an SEO by human resource or attended user. The gross income takes into account the capability of the organization in the generation of growth. Finally, the public grants per human resource or attended user measures the level of usage of public funding by the entity.

- Inclusive dimension or stakeholder participation. The degree of participation of stakeholders measures the level of inclusion of the needs of the SEO environment. The first indicator used in this study is related to the values and ideology of the SEO. The SEO ideology was defined by looking at the board composition. We codified on a scale the different political ideologies in Spain (from 0-4, with 
0 representing the most progressive political tendency and 4 indicating the most conservative one). We defined a specific value depending on the general tendency of the members of board. ${ }^{4}$ This definition was based on Gilman (1979), who established that the distinction between cultural conservatism versus progressivism should consider attitudes in favor of social change and individual rights and freedom. Affiliation with a political movement could represent this dimension and the values of the organization.

The second indicator that we propose is the number of financial stakeholders in the organization. The number of funders of the entities is determined based on the information contained in their annual reports. This variable can indicate the level of exclusiveness of some funders. Due to the importance of funding, and according to Powell and Friedkin (1987) and Smylie and Corcoran (2009), nonprofits often adapt their behavior to the interests and expectations of their funders. This variable measures the degree of adaption; thus, if we find only one funder, it is reasonable to assume that the adaptation to this funder will be higher.

Another aspect that may define the tendency toward increased confidence in stakeholders is the level of transparency within the SEO. Gandia (2008, 2009) and Saxton et al. $(2011,2014)$ considered an entity as showing transparent behavior when it encourages the disclosure of accounting information through the Internet. ${ }^{5}$ Therefore, this study identifies online accessibility as a third indicator of the participation of stakeholders or the inclusive dimension.

Finally, a fourth indicator of this dimension is used, that is, the integration of the general interest in the mission and aim of the SEO. This variable is related to the legal nature of the entity and was codified in this study as either 1 (general interest) or 0 (non-general interest). According to the Spanish legal framework, if the SEO is a foundation, it must take into account the promotion of the general interest. ${ }^{6}$ In the case of associations, the promotion of the general interest depends on the stamp of public utility. ${ }^{7}$ For commercial companies, we considered the general interest to be promoted when the legal framework puts it ahead of particular interests. $^{8}$

4 The political tendencies of the members of the board were determined from their electoral candidatures, which are public and free.

5 In relation to accessibility, we considered the websites of the SEOs. Each item represents the number of clicks in the website from a generic searcher to the annual report. For an entity without a website, the code was 0 .

6 Ley 50/2002, de 26 de diciembre, de Fundaciones (Law 50/2002, 26 December, of Foundations) [BOE núm. 310 de 27 de Diciembre de 2002].

7 Ley Orgánica 1/2002, de 22 de marzo, reguladora del Derecho de Asociación (Law 1/2002, 22 March, of Association Right) [BOE núm. 73 de 26 de Marzo de 2002].

8 For instance, in the case of sheltered workshops, the Spanish legal framework introduces some constraints in the promotion of the general interest (RD 2273/1985, de 4 de diciembre, de centros especiales de empleo de minusválidos-RD 2273/1985, 4 December, of sheltered workshops for disabled people) [BOE 9 de Diciembre de 1985]. 


\subsection{Data analysis}

Given the objective of this study, we started by carrying out a descriptive analysis of the indicators in terms of their position measures. ANOVA is used to examine the differences in economic and social activity between the entities invested in by each mutual fund (F1-F8). Tejedor (2012) identifies this test as a suitable analysis when the researcher is interested about the comparison between different samples. In this case, we compare those entities which got funding from a specific mutual fund and the entities which were not beneficiaries.

To estimate the probability of obtaining funds from each SMF, a set of binary logistic (logit) regressions is specified for each SMF. This sort of regression is recommended when the dependent variable has a binary composition (Silva and Barroso 2004). This methodology is preferred to the stratification trough categorical variables of the model variables because this technic enables to work with medium-sized samples and preserve the quantitative nature of the model variable. In our case, the logit model describes the relationship between the dichotomous dependent variable, which takes a value of 1 when the social entity perceives economic support from a specific SMF or a value of 0 otherwise, and $k$ explanatory variables $X_{1}, X_{2}, \ldots, X_{k}$. Because the dependent variable is binary (dichotomous), it follows the Bernoulli distribution; thus, $P_{j}=P\left(Y_{j}=1\right)$ is the probability of obtaining funding from a specific SMF, and $\left(1-P_{j}\right)$ is the probability of non-funding. The estimated model can be expressed as

$$
\ln \left[\frac{p\left(Y_{j}=1\right)}{1-p\left(Y_{j}=1\right)}\right]=\sum_{i=1}^{n} \beta_{i}^{*} X_{i}+\varepsilon,
$$

where $Y_{j}$ is the binary endogenous variable, and the subscript $j$ represents each SMF. The exogenous variables are represented by $X_{i}$, with $\varepsilon$ indicating the random disturbance. The parameters $\beta$ of the model measure the increase in the probability of receiving funds. In other words, the parameters are an indicator of the impact of the economic activity, social activity, and inclusive dimension on the funding obtained by each SEO. We have specified two types of model according to Berman and Wang (2011). The broad model includes all variables which have been exposed in the previous section, while the core model only includes those variables which are relevant in terms of the parametric $t$-test. This technic enables us to eliminate irrelevant variables, decreasing the variance of the parameters (Verbeek 2008). We have used the software SPSS 22.0 to develop the exposed data analysis.

\section{$4 \quad$ Results}

Table 2 shows a first approximation of the data, describing the position measurements by SMF and the results of the ANOVA test. This table is organized into three sections: economic activity, social activity, and inclusive dimension of the entity.

Regarding the economic activity, we can observe different results between the analyzed entities. In general, SMFs tend to fund companies with similar levels of economic profitability [min. ROA: $-0.125 \%$, max. ROA: $0.029 \%$ ] and financial return [min. ROE: $-0.458 \%$, max. ROE: 0.121\%]. The ANOVA test shows no differences between SMFs 


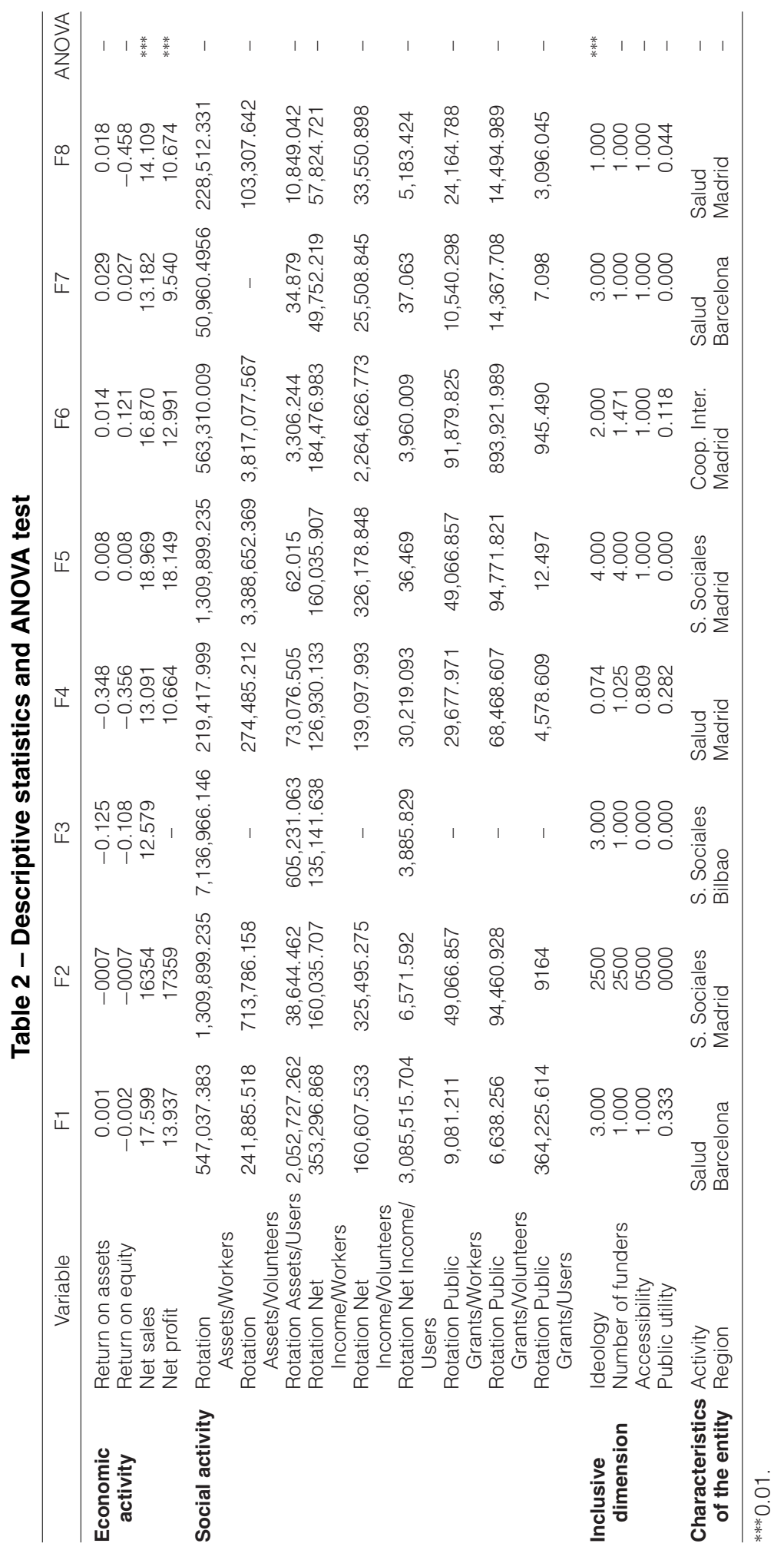


when these ratios are taken into account ( $p$-value $>0.10$ ). Thus, the achieved return is not a distinctive criterion for SMFs. However, different results are obtained when net sales and net profit are considered, with the ANOVA test showing significant differences between the analyzed SMFs ( $p$-value $<0.01$ ). The analysis of both items indicates that SMFs tend to fund entities that are able to create cash flows because all the SMFs show ratios higher than one [min. net sales: 12.579 , max. net sales: 18.969 ; min. net profit: 9.540, max. net profit: 18.149]. In other words, SMFs promote the creation of economic activity but are not concerned with the level of efficiency achieved by the social entity.

The social activity is not a distinctive element between SMFs. The ANOVA test shows that the decision to fund a specific social entity does not depend on the level of social activity developed ( $p$-value $>0.10$ ). Thus, we can affirm that, in general, the decision to fund a particular social entity is independent of the level of social activity, which is defined as investment, income, or public support by a human resource or user.

Finally, Table 2 also shows the impact of the proxies of the inclusive dimension and the characteristics of the social entity on the allocation of solidarity funds. The data indicate that SMFs prefer to fund activities related to health or social services and that they favor entities located in developed economic regions (Madrid, Catalonia, or Pays Basque). Moreover, the only notable characteristic is the ideology ( $p$-value $<0.01$ ). Hence, SMFs tend to fund entities with an ideology and values similar to their own. Other aspects, such as the number of funders, accessibility, or public utility, are not influential in the decision to fund an entity.

The descriptive statistics provide evidence of a single decision model in the distribution of solidarity funds. In general, SMFs do not take into account social achievements, but they promote entities that develop economic activity and share their ideological characteristics. In any case, this preliminary evidence needs to be tested.

Thus, a set of logistic regression models is developed to test the results. Tables $3-5$ show the goodness of fit and the different estimated parameters. Specifically, Tables 3 and 4 present the results for economic and social activity, and Table 5 shows the results for the inclusive dimension.

In relation to the goodness of fit, the different models show an acceptable fit when the explained variable is part of the decision criteria of the SMF (Nagelkerke's $R^{2}>0.50$ ). For all SMFs, a broad model and a core model are estimated. The core model includes only those parameters that have a significant influence in the probability of obtaining funding from an ESFM. The interpretation of the parameters has to consider the logistic component of the model; thus, a negative sign for a parameter means that the indicator decreases the probability of obtaining funding for these entities, whereas a positive sign indicates otherwise.

Firstly, it should be noted that the SMFs F3, F5, and F7 fund only one entity. For F3 and F7, this entity is a foundation created by the holder of the SMF, whereas F5 funds a generic entity and follows the policy defined by F2, with similar values for some items (see Table 1). For this reason, in this first group, the decision is ex ante and not dependent on the activity of the SEO. In such cases, a social entity could find it difficult to obtain funds from these SMFs.

Regarding the economic activity, we can observe that all SMFs apply this element in their decision-making process $(p$-value $<0.05)$. In particular, SMFs take into account 
Table 3 - Decisional model mutual funds: economic activity

\begin{tabular}{|c|c|c|c|c|c|c|}
\hline Mutual fund & Estimator year & Return on assets & Return on equity & Net sales & Net profit & $R^{2}$ \\
\hline \multirow[t]{10}{*}{ F1 } & Est.2013 & -17.306 & -14.938 & -0.547 & 0.430 & 0.956 \\
\hline & Est.2013 & - & - & $-0.305^{* * *}$ & - & 0.951 \\
\hline & Est.2012 & -6.060 & -0.033 & $-0.530^{*}$ & 0.249 & 0.962 \\
\hline & Est.2012 & - & - & $-0.354^{* * *}$ & - & 0.960 \\
\hline & Est.2011 & -12.186 & -0.026 & $-0.501^{* *}$ & 0.234 & 0.970 \\
\hline & Est.2011 & - & - & $-0.363^{* * *}$ & - & 0.968 \\
\hline & Est.2010 & -2.810 & -1.788 & $-0.640^{* *}$ & 0.391 & 0.970 \\
\hline & Est.2010 & - & - & $-0.358^{* * *}$ & - & 0.967 \\
\hline & Est.2009 & -8.367 & -0.387 & $-0.571^{* *}$ & 0.321 & 0.969 \\
\hline & Est.2009 & - & - & $-0.357^{* * *}$ & - & 0.966 \\
\hline \multirow[t]{10}{*}{ F2 } & Est.2013 & 1.067 & -1.929 & -0.111 & -0.326 & 0.973 \\
\hline & Est.2013 & - & - & - & $-0.475^{* * *}$ & 0.973 \\
\hline & Est.2012 & 0.281 & -0.149 & $-0.553^{*}$ & 0.188 & 0.971 \\
\hline & Est.2012 & - & - & $-0.392^{* * *}$ & - & 0.970 \\
\hline & Est.2011 & 1.321 & 0.049 & $-0.944^{* * *}$ & $0.583^{* *}$ & 0.980 \\
\hline & Est.2011 & - & - & $-0.930^{* * * *}$ & $0.561^{* *}$ & 0.979 \\
\hline & Est.2010 & -0.319 & -0.068 & $-0.618^{* *}$ & 0.254 & 0.973 \\
\hline & Est.2010 & - & - & $-0.389^{* * *}$ & - & 0.972 \\
\hline & Est.2009 & 4.619 & -0.428 & $-0.794^{*}$ & 0.452 & 0.979 \\
\hline & Est.2009 & - & - & $-0.381^{* * *}$ & - & 0.974 \\
\hline \multirow[t]{10}{*}{ F4 } & Est.2013 & -0.208 & -0.484 & $0.425^{* *}$ & -0.378 & 0.643 \\
\hline & Est.2013 & - & - & $0.133^{* * *}$ & - & 0.620 \\
\hline & Est.2012 & 4.574 & -0.069 & $0.222^{*}$ & -0.082 & 0.735 \\
\hline & Est.2012 & - & - & $0.175^{* * *}$ & - & 0.730 \\
\hline & Est.2011 & $8.444^{*}$ & 0.003 & $0.428^{* * *}$ & $-0.397^{* *}$ & 0.728 \\
\hline & Est.2011 & - & - & $0.362^{* * *}$ & $-0.265^{*}$ & 0.711 \\
\hline & Est.2010 & 2.204 & 1.294 & $0.391^{* * *}$ & $-0.325^{* *}$ & 0.727 \\
\hline & Est.2010 & - & - & $0.162^{* * *}$ & - & 0.704 \\
\hline & Est.2009 & 1.020 & 0.245 & $0.421^{* * *}$ & $-0.356^{* *}$ & 0.719 \\
\hline & Est.2009 & - & - & $0.399^{* * *}$ & $-0.319^{* *}$ & 0.715 \\
\hline \multirow[t]{10}{*}{ F6 } & Est.2013 & -0.273 & 1.457 & -0.225 & 0.089 & 0.690 \\
\hline & Est.2013 & - & - & $-0.148^{* * *}$ & - & 0.681 \\
\hline & Est.2012 & -6.632 & $1.246 *$ & -0.146 & -0.024 & 0.731 \\
\hline & Est.2012 & - & - & $-0.166^{* * *}$ & - & 0.702 \\
\hline & Est.2011 & $-19.277^{* *}$ & 0.007 & $-0.240^{* *}$ & 0.162 & 0.767 \\
\hline & Est.2011 & $-16.815^{* *}$ & - & $-0.129^{* * *}$ & - & 0.763 \\
\hline & Est.2010 & -1.913 & -1.061 & $-0.194^{*}$ & 0.060 & 0.717 \\
\hline & Est.2010 & - & - & $-0.163^{* * *}$ & - & 0.706 \\
\hline & Est.2009 & -7.783 & -0.276 & $-0.313^{* * *}$ & 0.242 & 0.718 \\
\hline & Est.2009 & - & - & $-0.160^{* * *}$ & - & 0.697 \\
\hline \multirow[t]{10}{*}{ F8 } & Est.2013 & -0.727 & -6.336 & $-0.445^{*}$ & 0.394 & 0.796 \\
\hline & Est.2013 & - & - & $-0.179^{* * *}$ & - & 0.781 \\
\hline & Est.2012 & -3.823 & 0.043 & $-0.308^{*}$ & 0.080 & 0.894 \\
\hline & Est.2012 & - & - & $-0.261^{* * *}$ & - & 0.893 \\
\hline & Est.2011 & -2.921 & -0.013 & $-0.433^{* * *}$ & 0.293 & 0.858 \\
\hline & Est.2011 & - & - & $-0.224^{* * *}$ & - & 0.850 \\
\hline & Est.2010 & -1.468 & -0.963 & $-0.480^{* * *}$ & 0.326 & 0.891 \\
\hline & Est.2010 & - & - & $-0.244^{* * *}$ & - & 0.884 \\
\hline & Est.2009 & 0.332 & -0.150 & $-0.327^{*}$ & 0.096 & 0.898 \\
\hline & Est.2009 & - & - & $-0.257^{* * *}$ & - & 0.898 \\
\hline
\end{tabular}

*0.10; **0.05; ***0.01 


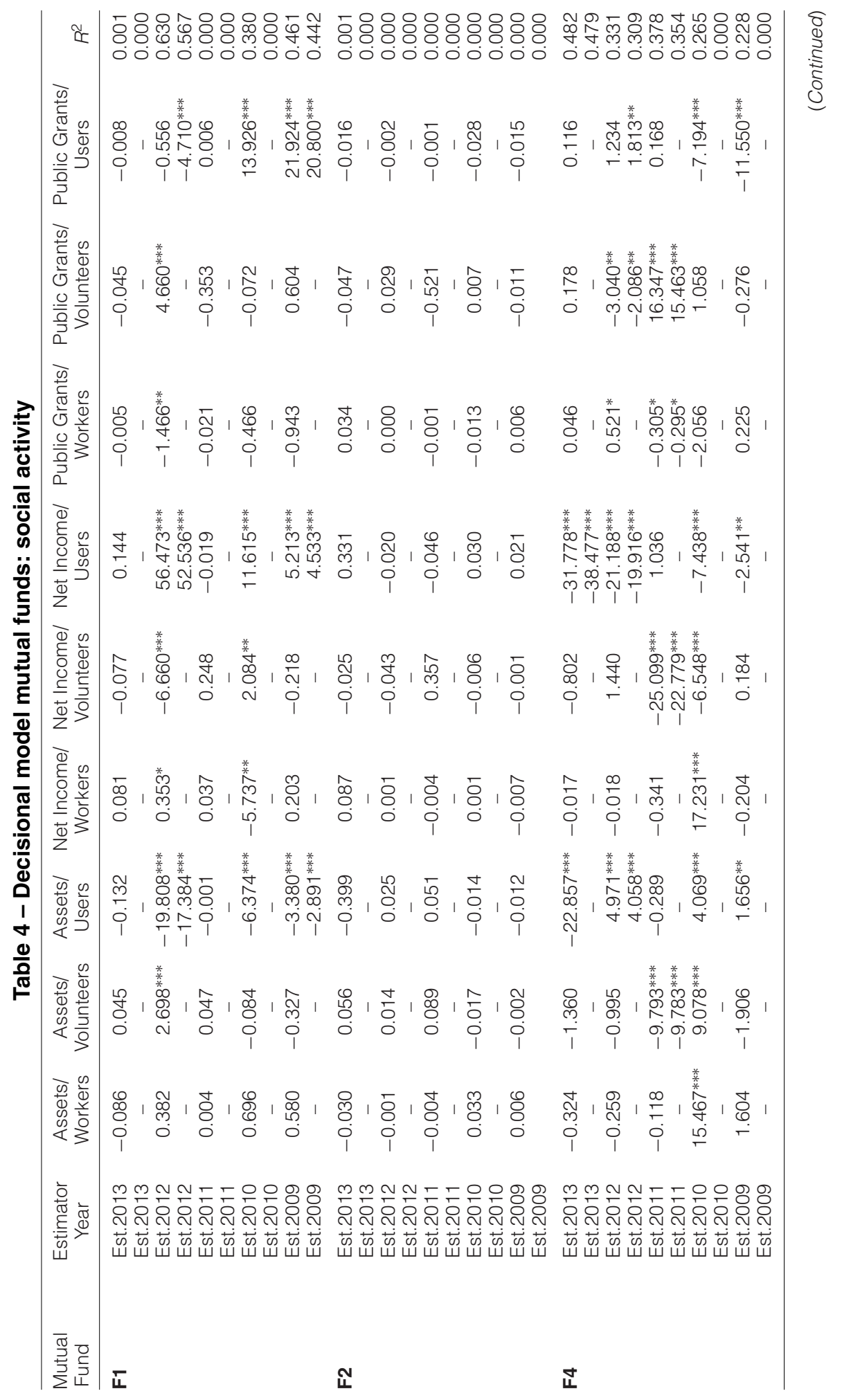




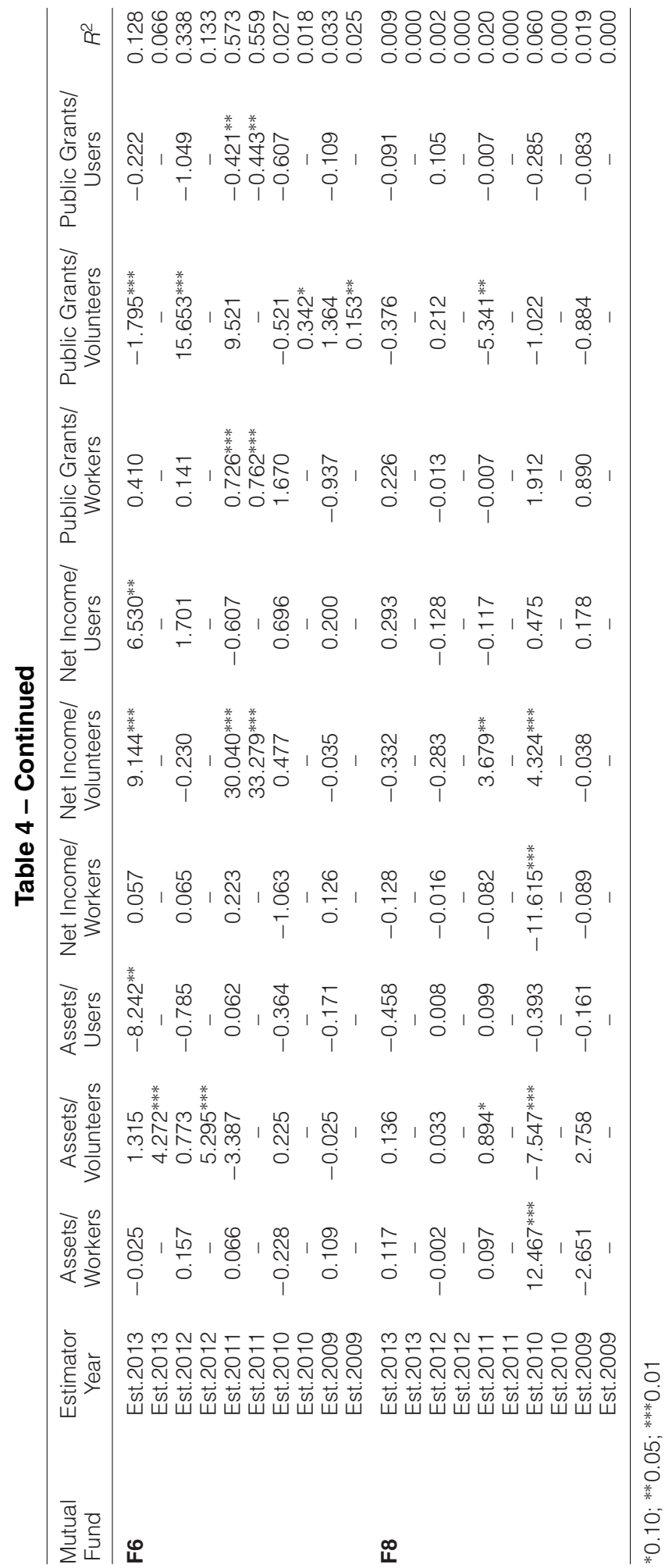




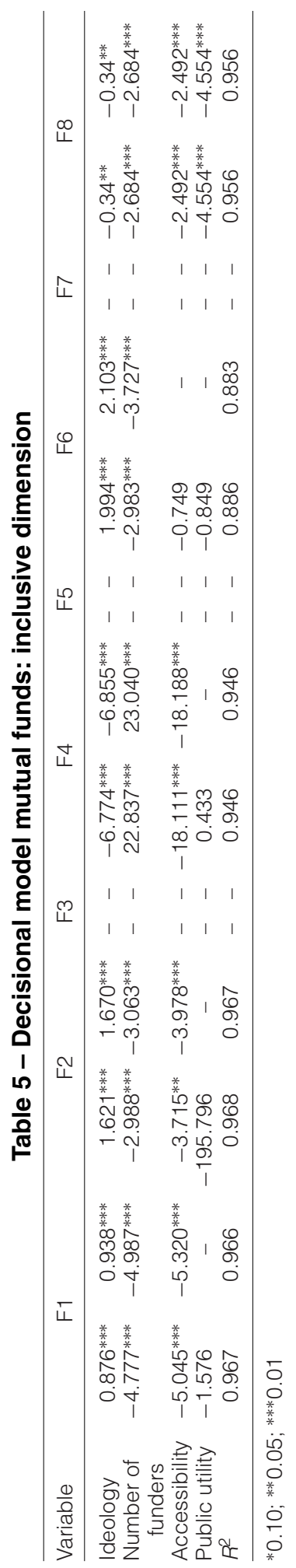


the ability of an entity to promote sales. The Spanish SMFs, with the exception of F4 (see Table 4), tend to potentiate SEOs with low sales growth (est. $2009<0.00$; est. 2013 $<0.00$ ). Thus, the support of an SMF is perceived as a kind of substitutive funding for economic activity. Only F4, the holder of which is a commercial bank, promotes the development of economic activity (est. $2009>0.00$; est. $2013>0.00$ ).

The analysis of the social activity indicates diversity in SMF behaviors. It is interesting to note that two SMFs, F2 and F8, do not consider social activity when they decide on the allocation of solidarity funding (see Tables 3 and 4). This idearium is not rare among Spanish SMFs given that two other funds consider social activity only in special circumstances. As shown in Table 4, F4 started using social criteria, such as the result of economic recession ( $p$-value $2009>0.10, p$-value $2010>0.10$ ). Further, Table 4 shows that F1 applied social criteria in the worst years of the economic recession ( $p$-value $2009<0.10, p$-value $2012<0.10$ ). In both cases, these SMFs tended to use the attended users as criterion, potentiating entities with a high level of income per user (est. $>0.00$ ). A positive sign indicates that when the SMF decides to promote a social entity, it does not consider other social elements, such as the volunteers or workers ( $p$-value $>0.10)$. However, a different behavior is observed with F6, which also considers aspects related to volunteers (est. $>0.00$ ) and workers (est. $2011>0.00$ ).

Finally, Table 5 shows the impact of the inclusive dimension of the SEO. The descriptive statistics indicate that the ideology of the SMF is one of its most important characteristics ( $p$-value $<0.01$ ). The negative sign for F4 (est. -6.855) means that this SMF tends to fund entities whose management board includes members of social democratic political parties. The positive sign (est. $>0.00$ ) indicates the opposite; that is, the SMF tends to promote entities managed by members of conservative political parties. The logit regression also shows that the number of funders is the second consideration of a social entity seeking funding from an SMF ( $p$-value $<$ 0.01). In general, the estimated parameters are negative (est. $<0.00$ ); thus, SMFs prefer funding one social entity exclusively. An exception is F4, which promotes entities that use funds from different suppliers. Other characteristics, such as accessibility of the entity or public utility declaration, are residual aspects that not all SMFs take into account.

Our results therefore indicate that when deciding to fund a social entity, an SMF can have three possible behaviors:

(a) In one group of SMFs (F3, F5 and F7), the decision to fund an SEO is ex ante. These SMFs promote an entity that is related to their holder or has significant presence in the Spanish society. They do not consider the social or economic activity of the entity.

(b) A second group of SMFs (F2 and F8) considers only the level of economic activity, understood as net sales, promoted by the SEO. One possible explanation for this model is the necessity of gaining customer loyalty. In this group, the SMF could be a strategic tool in the marketing policy of the holder bank.

(c) Finally, a third group (F1, F4 and F6) takes into account the economic and social elements of the entity. This group considers the attended users and/or aspects related to volunteers or workers as factors in the allocation of solidarity funds. 
In all cases, three common elements can be observed: the promotion of commercial activity, the ideology, and the relationships with other funders. These three elements are the general characteristics that allow us to model the behavior of solidarity mutual funds.

\section{Conclusions and implications}

The obtained results indicate that SMFs tend to fund SEOs with higher levels of development of commercial activity and favor those SEOs that share their specific ideology and values and have an exclusive relationship with the main funder. Some unique characteristics in the behavior of some mutual funds are observable. These characteristics define the mutual fund and its idea of solidarity.

In many cases, the economic activity of the SEO is found to be a decision criterion when the mutual fund designs its allocation of funding. Thus, the mutual fund is perceived as a part of the marketing policy of the holder bank. This result brings to light a new way to obtain a competitive advantage. That is, if the mutual fund adopts a solidarity component, the holder bank will have the opportunity to attract SEOs as customers, and the solidarity component will thus represent an added value in relation to competitors. As a consequence, the concept of solidarity of the mutual fund will no longer exist because solidarity will become merely a brand oriented toward gaining customers.

In the general model, the promotion of the participation of stakeholders, specifically financial stakeholders, is observed to be a decision criterion for SMFs. However, the mutual fund is not interested in accessibility or supporting the general interest. In Spain, SMFs foster social entities that share their values and ideology. This result is particularly worrying if we consider that, in general, the social activity of the SEO is not a decision criterion. In other words, the users or human resources are not included in the definition of solidarity as applied in Spanish SMFs. Therefore, there is no guarantee that this financial product will fulfill the objectives that motivated its creation.

These results have two implications. Mutual funds related to socially responsible investment have created mechanisms to ensure that socially responsible companies are included in their portfolios. Thus, they should consider the possible application of these mechanisms in the allocation of solidarity funding. For instance, the definition of an idearium or the composition of a solidarity board could serve as alternatives in the selection of an SEO. The idearium is a document that defines the principles that govern the concept of solidarity of the mutual fund, whereas the solidarity board is a sort of control board tasked with monitoring the allocation decisions. These practices are currently being implemented in socially responsible investment (Argandoña 2000; De la Cuesta 2005) and can be easily applied to solidarity funding.

Moreover, it is necessary to train the staff and, especially, the managers of SMFs so that they would recognize the utility of the information provided by social rating agencies (Sihna 2006). Of course, such usefulness requires a process of preparation that starts in the SEO. If the SMFs promote the verification of their activities, the objectivity of their allocation decision will increase. Thus, any social entity that 
seeks to obtain solidarity funding should know these possibilities and which aspects to promote.

Finally, we note some limitations of our study. First, our paper is centered in Spain. Thus, the cultural environment and specific aspects of the Spanish legal framework could condition our results. Moreover, our study covered a specific period characterized by an economic crisis. For these reasons, further research about this financial product is required given that SMFs could represent a key tool in the economic recovery of the nonprofit sector.

\section{REFERENCES}

ASOCIACIÓN ESPAÑOLA DE CONTABILIDAD Y ADMINISTRACIÓN DE EMPRESAS 2015, La empresa social: marco conceptual, contexto e información. Asociación Española de Contabilidad y Administración de Empresas, Madrid.

ARGANDOÑA A. and SARSA D., 2000, 'Los Fondos Éticos y la promoción de la ética inversora', Papeles de Ética, Economía y Dirección, 5, 1-18.

BELLOSTAS PÉREZ-GRUESO A. J. and LÓPEZ ARCEIZ F. J., 2014, 'Situación actual de los fondos éticos y solidarios. Una perspectiva comparada', Boletín Económico de ICE, 3057, 57-70.

BELLOSTAS A. J., LÓPEZ-ARCEIZ F. J. and MATEOS L., 2016, 'Social value and economic value in social enterprises: value creation model of Spanish sheltered workshops', VOLUNTAS: International Journal of Voluntary and Nonprofit Organizations, 27(1), 367-391.

BERMAN E., and WANG X., 2011, Essential Statistics for Public Managers and Policy Analysts, CQ Press, Thousand Oaks, CA.

BILLIS D. (ed.), 2010, Hybrid Organizations and the Third Sector: Challenges for Practice, Theory and Policy, Palgrave Macmillan, London.

BORZAGA C. and GALERA G., 2014, 'New trends in the nonprofit sector in Europe: The emergence of social enterprises', in E. Costa, L. D. Parker and M. Andreaus (eds.), Accountability and Social Accounting for Social and Non-Profit Organizations, Emerald Group Publishing, Bingley, UK, pp. 89-110.

BRIDGES VENTURES 2012, Ten Year Report. A Decade of Investing for Impact and Sustainable Growth, Bridges Ventures, London.

CHAVES R., MONZÓN J. L. and TOMÁS-CARPI J. A., 1999, La Economía Social y la Política Económica, Tirant Lo Blanch, Valencia.

CHERUVALATH R., 2016, Need for a shift from a philanthropic to a humanistic approach to corporate social responsibility. Annals of Public and Cooperative Economics (first online).

CRIFO P. and MOTTIS N., 2016, 'Socially responsible investment in France'. Business and Society, 55(4), 576-593.

DEFOURNY J. and NYSSENS M., 2008, 'Social enterprise in Europe: Recent trends and developments', Social Enterprise Journal, 4(3), 202-228. 
DE LA CUESTA GONZÁLEZ M., 2005, 'Las inversiones socialmente responsables como palanca de cambio económico y social', Revista trimestral latinoamericana y caribeña de desarrollo sostenible, 3(11), 23-42.

DILLENBURG S., GREENE T. and EREKSON O. H., 2003, 'Approaching socially responsible investment with a comprehensive ratings scheme: Total social impact', Journal of Business Ethics, 43(3), 167-177.

DI ZHANG D. and SWANSON L. A., 2013, 'Social entrepreneurship in nonprofit organizations: An empirical investigation of the synergy between social and business objectives', Journal of Nonprofit and Public Sector Marketing, 25(1), $105-125$.

DOHERTY B., HAUGH H. and LYON F., 2014, 'Social enterprises as hybrid organizations: A review and research agenda', International Journal of Management Reviews, 16(4), 417-436.

EMERSON J., 2006, 'Moving ahead together: Implications of a blended value framework for the future of social entrepreneurship', in A. Nicholls (ed.), Social Enterpreneurship. New Models of Sustainable Social Change, Oxford University Press, New York, pp. 391-406.

ENTINE J., 2003, 'The myth of social investing', Organization and Environment, 16(3), $352-368$.

EUROPEAN UNION Strategy 2009, 'Communication from the Commission: A Strategy for smart, sustainable and inclusive growth', Brussels, 3.3.2010 COM(2010) 2020.

EUROPEAN COMMISSION 2011, 'Social business initiative', Brussels, 25.10.2011, COM (2011) 682 final.

EUROPEAN ECONOMIC AND SOCIAL COMMITTEE (EESC) 2015, 'Social impact investing and its role in the future social public/private investments: continuing dialogue', Brussels, 16 February 2015.

EVANS T. G., 1999, 'Demystifying nonparticipation in microcredit: A population-based analysis', World Development, 27, 419-430.

FAYOLLE A. and MATLAY H. (eds.), 2010, Handbook of Research on Social Entrepreneurship, Edward Elgar, Cheltenham, UK.

GALERA G., 2015, Analyzing Social Enterprise research from a European perspective. International Congress on Social Business and Entrepreneurship, EURICSE. [UFPR 4 May 2015].

GANDÍA J. L., 2008, 'Determinants of internet-based corporate governance disclosure by Spanish listed companies', Online Information Review, 23(6), 791-817.

GANDÍA J. L., 2009, 'Internet disclosure by nonprofit organizations: Empirical evidence of nongovernmental organizations for development in Spain', Nonprofit and Voluntary Sector Quarterly, 40, 57-78.

GILMAN S. C., 1979, 'Progressiveness and conservatism: the fundamental dimensions of ideological controversy and their relationship to social class', Journal of Politics, 41(3), 988-990.

GIRARD E. C., RAHMAN H. and STONE B. A., 2007, 'Socially responsible investments: Goody-two-shoes or bad to the bone?' Journal of Investing, 16(1), 96-110. 
GUTIÉRREZ-NIETO B., SERRANO-CINCA C. and MOLINERO C. M., 2009, 'Social efficiency in microfinance institutions', Journal of the Operational Research Society, 60(1), 104-119.

HULGÅRD L., 2010, 'Discourses of social entrepreneurship - Variations of the same theme?' EMES Working Paper No. 10/01.

INVERCO 1999, 'Circular sobre utilizacion por las instituciones de inversion colectiva de la denominacion "ético", "ecológico" o cualquier otro que incida en aspectos de responsabilidad social' [15th November 1999].

INVERCO 2014, 'Circular sobre la aplicación de criterios medioambientales, sociales y de gobierno corporativo (ESG) en la política de inversión de las instituciones de inversión colectiva' [8 April 2014].

JALIU D. D. and RĂVAR A. S., 2013, 'Mechanisms for financing social enterprisesConstraints and opportunities. A case study of Romania', 4th CIRIEC International Research Conference on Social Economy (University of Antwerp, October 24-26, 2013).

JÉGOUREL Y. and MAVEYRAUD S., 2009, 'The financial performance of solidarity investment funds: The French case'. Bankers, markets and investors. Bankers, markets and investors, 1-18.

KERLIN J., 2006, 'Social enterprise in the United States and Europe: Understanding and Learnig from the differences', VOLUNTAS: International Journal of Voluntary and Nonprofit Organizations, 17(3), 247-263.

KINGSTON J. and BOLTON M., 2004, 'New approaches to funding not-for-profit organisations', International Journal of Nonprofit and Voluntary Sector Marketing, 9(2), 112-121.

Ley 50/2002, de 26 de diciembre, de Fundaciones (Law 50/2002, $26^{\text {th }}$ December, of Foundations) [BOE núm. 310 de 27 de Diciembre de 2002].

Ley Orgánica 1/2002, de 22 de marzo, reguladora del Derecho de Asociación (Law 1/2002, $22^{\text {th }}$ March, of Association Right) [BOE núm. 73 de 26 de Marzo de 2002].

Ley 35/2003, de 4 de noviembre, de Instituciones de Inversión Colectiva (Law 35/2003, $4^{\text {th }}$ November, of Collective Investments Institutions) [BOE núm. 265 de 5 de Noviembre de 2003].

LIKET K. and MAAS K., 2016, 'Strategic philanthropy corporate measurement of philanthropic impacts as a requirement for a "happy marriage" of business and society', Business and Society, 55(6), 889-921.

LÓPEZ-ARCEIZ F. J., BELLOSTAS A. and RIVERA TORRES M. P., 2016, 'The effects of resources on social activity and economic performance in social economy organizations', Nonprofit Management and Leadership, 26(4), 499-511.

LOZANO J. M., ALBAREDA L. and BALAGUER M. R., 2006, 'Socially responsible investment in the Spanish financial market', Journal of Business Ethics, 69(3), 305316.

MANO R. S., 2014, 'Networking modes and performance in Israel's nonprofit organizations', Nonprofit Management and Leadership, 24(4), 429-444. 
MANO R., 2015, 'Funding allocations in Israel: An empirical assessment of the new philanthropy approach', VOLUNTAS: International Journal of Voluntary and Nonprofit Organizations, 1-16.

MUÑOZ-TORRES M. J., FERNÁNDEZ-IZQUIERDO M. Á. and BALAGUER-FRANCH M. R., 2004, 'The social responsibility performance of ethical and solidarity funds: an approach to the case of Spain', Business Ethics: A European Review, 13(2-3), 200-218.

NAVAJAS S., SCHREINER M., MEYER R. L., GONZALEZ-VEGA C. and RODRIGUEZ-MEZA J., 2000, 'Microcredit and the poorest of the poor: theory and evidence from Bolivia', World Development, 28(2), 333-346.

ORTAS E. and MONEVA J. M., 2011, 'Sustainability stock exchange indexes and investor expectations: Multivariate evidence from DJSI-Stoxx', Spanish Journal of Finance and Accounting/Revista Española de Financiación y Contabilidad, 40(151), 395-416.

PATOMÄKI H., 2009, 'Neoliberalism and the global financial crisis', New Political Science, 31(4), 431-442.

PIRSON M., 2012, 'Social entrepreneurs as the paragons of shared value creation? A critical perspective', Social Enterprise Journal, 8(1), 31-48.

PORTER M. and KRAMER M. R., 2006, 'Estrategia y sociedad', Harvard Business Review, 84(12), 42-56.

PORTER M. E. and KRAMER M. R., 2012, 'Shared Value: Die brücke von corporate social responsibility zu corporate strategy', in A. Schneider and R. Schmidpeter (eds.), Corporate Social Responsibility, Springer, Berlin, pp. 137-153.

POWELL W. W. and FRIEDKIN R., 1987, 'Organizational change in nonprofit organizations', in W. W. Powell (ed.), The Nonprofit Sector, Yale University Press, New Haven, CT, pp. 180-192.

PROUTEAU L., and TCHERNONOG V., 2015, 'Changes in the public funding of french voluntary associations: evidence, prospects and challenges', Annals of Public and Cooperative Economics, 86(2), 291-316.

PwC Foundation, 2013, La reacción del tercer sector social ante la crisis. PwC, Madrid.

QUINTÃO C., 2007, 'Empresas de inserción y empresas sociales en Europa', Revista CIRIEC-España, 59, 33-60.

RAHIM H. L., MOHTAR S. and RAMLI A., 2015, 'The effect of social entrepreneurial behaviour towards organizational performance: a study on bumiputera entrepreneurs in Malaysia', International Academic Research Journal of Business and Technology, 1(2), 117-125.

RAMAYAH T., LEE J. W. C. and IN J. B. C., 2011, 'Network collaboration and performance in the tourism sector', Service Business, 5(4), 411-428.

Real Decreto 2273/1985, de 4 de diciembre, de centros especiales de empleo de minusválidos-(Real Decreto 2273/1985, $4^{\text {th }}$ December, of sheltered workshops for disabled people) [BOE 09 de Diciembre de 1985]. 
RENNEBOOG L., HORST J. T. and ZHANG C., 2008a, 'Socially responsible investments. Institutional aspects, performance, and investor behaviour', Journal of Finance Banking, 32, 1723-1742.

RENNEBOOG L., TER HORST J. and ZHANG C., 2008b, 'The price of ethics and stakeholder governance: The performance of socially responsible mutual funds'. Journal of Corporate Finance, 14(3), 302-322.

Plan General de Contabilidad a las entidades sin fines lucrativos [Accounting General Plan of nonprofit organizations] Resolution on March 26, 2013 (BOE no. 85 on April 9, 2013).

Plan General de Contabilidad a las pequeñas y medianas entidades sin fines lucrativos [Accounting General Plan of Small and Medium nonprofit organizations] Resolution on March 26, 2013 (BOE no. 86 on April 10, 2013).

RUST R. T., AMBLER T., CARPENTER G. S., KUMAR V. and SRIVASTAVA R. K., 2004, 'Measuring marketing productivity: Current knowledge and future directions'. Journal of Marketing, 68(4), 76-89.

SANCHIS-PALACIO J. R., CAMPOS-CLIMENT V. and MOHEDANO-SUANES A., 2013, 'Management in social enterprises: the influence of the use of strategic tools in business performance', International Entrepreneurship and Management Journal, $9(4), 541-555$.

SAXTON G. D., KUO J. S. and HO Y. C., 2011, 'The determinants of voluntary financial disclosure by nonprofit organizations', Nonprofit and Voluntary Sector Quarterly, 41(6), 1051-1071.

SAXTON G. D., NEELY D. G. and GUO C., 2014, 'Web disclosure and the market for charitable contributions', Journal of Accounting and Public Policy, 33(2), 127-144.

SILVA L. C. and BARROSO I. M., 2004, 'Regresión Logística', Cuadernos de Estadística, 27, 1-173.

SINHA F., 2006, 'Social rating and social performance reporting in microfinance: towards a common framework', SEEP Network, Washington, DC.

SCHMIDT V. A., 2016, 'The roots of neo-liberal resilience: Explaining continuity and change in background ideas in Europe's political economy', British Journal of Politics and International Relations, 18(2), 318-334.

SMYLIE M. A. and CORCORAN T. B., 2009, 'Nonprofit organizations and the promotion of evidence-based practice in education', Annual Meeting of the American Educational Research Association, AER, San Francisco, pp. 111-136.

SOCIAL INVESTMENT FORUM 2014, Community Investing. http://ussif.org/ [8th January 2016].

STAGARS M., 2014, 'Impact investment funds for frontier markets in Southeast Asia: Creating a platform for institutional capital, high-quality foreign direct investment, and proactive policy', Journal of Asset Management, 15(6), 347-352.

TAN W. L. and YOO S. J., 2015, 'Social Entrepreneurship Intentions of Nonprofit Organizations', Journal of Social Entrepreneurship, 6(1), 103-125.

TEJEDOR F.J., 2012, 'Análisis de la varianza', Cuadernos de Estadística, 3, 1-132. 
VALOR C., PALOMO R., ITURRIOZ J. and MATEU J. L., 2007, 'Socially responsible investments among savings banks and credit unions: empirical findings in the Spanish context', Annals of Public and Cooperative Economics, 78(2), 301-326.

VAN BEURDEN P. and GÖSSLING T., 2008, 'The worth of values-a literature review on the relation between corporate social and financial performance', Journal of Business Ethics, 82(2), 407-424.

VERBEEK M., 2008, A Guide to Modern Econometrics, Wiley, Chichester, UK.

WILKINSON C., MEDHURST J., HENRY N. and WIHLBORG M., 2015, 'A map of social enterprises and their eco-systems in Europe', Executive Summary, ICF Consulting Services, European Commission.

WILSON K. E., 2014, 'New investment approaches for addressing social and economic challenges', OECD Science, Technology and Industry Policy Paper No. 15.

WILSON F. and POST J. E., 2013, 'Business models for people, planet (\& profits): exploring the phenomena of social business, a market-based approach to social value creation'. Small Business Economics, 40(3), 715-737. 